DOI: https://doi.org/10.18524/2519-2523.2021.16.245744

УДК 94(477)“1945/1964”

\title{
PETRO SHELEST'S ACTIVITIES TO PRESERVE THE MEMORY OF THE COSSACKS
}

\section{Yuriy Prysyazhnyuk}

Post-graduate student of the

Odesa I. I. Mechnikov National

University

2, Dvoryanska Str., Odesa, 65082,

Ukraine

O R C I D : h t t p s : / /

o r c i d.or g / 0000 -

0001-5880-3568

E-mail: yuripris4@gmail.com

Citation: Prysyazhnyuk, Y. (2021)

Petro Shelest's activities to preserve the memory of the Cossacks.

Chornomors 'ka mynuvshyna, vol. 16, pp. $98-103$.

Submitted: 14.09.2021

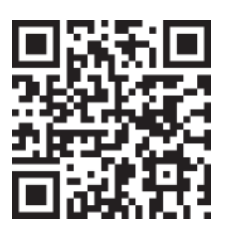

\section{Annotation}

The purpose of the article is to cover Petro Shelest's activities to preserve the memory of the Cossacks. I aimed to cover the political path of Petro Shelest. What he was guided by when he was first secretary. What cultural monuments he reconstructed and restored during his reign.

The article clarifies the features of socio-political activity of the Ukrainian Soviet Republic. The set of documents used in the work makes it possible to objectively assess the activities of Petro Shelest. The use of historical-systematic method of research made it possible to reproduce the main character of the hero.

The article also identifies the main architectural complexes that were reconstructed during the reign of Petro Shelest. What historical sculptures have been completely restored. What Petro Shelest paid attention to when he was in power and what bothered him about the history of Ukraine. The activity of the Ukrainian party leadership, which was aimed at preserving the memory of the Cossacks is considered.

Key words: Cossacks, Petro Shelest, the Ukrainian Soviet Republic, cultural monuments.

\section{ДІЯЛЫНІСТ ПЕТРА ШЕЛЕСТА ПО ЗБЕРЕЖЕННЮ ПАМ' ЯТІ ПРО КОЗАЦТВО}

\section{Юрій Присяжнюк}

Аспірант кафедри історії України Одеський національний університет імені I. I. Мечникова Вул.Дворянська, 2, м. Одеса, 65025, Україна

ORCID: https:// orsid.org / 00000001-5880-3568

E-mail: yuripris4@gmail.com

Цитування: Присяжнюк Ю.

Діяльність П. Шелеста по збереженню пам'яті про козацтво. Чорноморська минувшина: записки Відділу історії козацтва на півдні України: зб. наук. пр. / за. ред. В.А. Смолія. Одеса: ФОП Бондаренко М.О., 2021. Вип. 16. C. 98-103.

Отримано: 14.09.2021 р.

\section{Анотація}

Стаття висвітлюе діяльність першого секретаря Комуністичної партії України (1963-1972), Петра Шелеста щодо збереження пам'яті про козачтво. 3'ясовано, причини позитивного ставлення Шелеста до козацької тематики, зокрема сприяла цьвому козацька родина батька $i$ діда, визначено головні архітектурні комплекси та пам'ятники, які були реконструйовані в період керівництва Петра Шелеста $i$ стосувались тематики, пов'язаної з історією козачтва. Відзначено, як ия тематика відобразилась у енциклопедичних та інших виданнях, підготованих в часи лібералізації та десталінізації. Показано, як змінювалося ставлення загальнорадянського керівництва до діяльності П. Шелеста, $i$ як ие відобразилось на збереженні пам'яті про козаитво.

Ключові слова: козацтво, Петро Шелест, Українська Радянська Соџіалістична Республіка, пам'ятки культури. 
Україна періоду перебування у владі першого секретаря ЦК КПРС, голови Ради Міністрів СРСР М. С. Хрущова має велику кількість досліджень. На посаді Генерального секретаря яку обіймав Хрущов в Україні змінився не один керівник партії та уряду, але самим значущим став Петро Юхимович Шелест, який став першим секретарем Комуністичної партії Радянської України. Про нього написано багато історичних монографій з оцінкою роботи, однак мета даної публікації з'ясувати, що саме було зроблено Петром Юхимовичем по збереженню пам' яті про козацтво. Для цього треба розглянути як формувались його погляди на історію власної родини та України, в цілому. Звернемося до біографії Петра Шелеста.

Петро Юхимович Шелест народився 1 (за новим стилем 14) лютого 1908 р. у селі Андріївка Зміївського повіту Харківської губернії (тепер Харківська область). Батько, Юхим Дмитрович, рано втратив першу дружину котру дуже любив та кохав, від неї зосталися діти: Яків і Агафія. Після смерті першої дружини він одружився вдруге на вдові Марії Павлюк. У неї вже був син Семен. Незабаром у них з'явилося ще четверо дітей: Марія, Петро, Дмитро та Юлія. Як згадував Петро Юхимович: «Коли я народився батькові моєму було вже за 60 років. Усе життя я його пам'ятаю тільки літнім, але красивим, струнким, підтягнутим, міцним. У батька була сива огрядна борода, вуса і велика шевелюра волосся, зачесаного на потилицю. Скільки я пам'ятаю, він завжди і незмінно палив люльку і ніколи з нею не розлучався. Батько був суворий, завжди замкнуто-зосереджений, небалакучий, не любив теревенити. Якщо у нього і були друзі, то тільки літні, перевірені товариші через сумісну довголітню службу в армії» [11, с. 27]. Батько Петра Юхимовича мав георгіївські хрести усіх чотирьох ступенів. Це врятувало його від відповідальності після страйку на заводі, де він працював, коли почалися протести 1905 р. Петро спогадував, що “батько був людиною грамотною та розумною, багато читав, писав непогано. До нього підходили багато людей, котрих було підготувати на якенебудь "прохання" або “звернення", де потрібно було рахувати та робити дуже складні розрахунки”. Батько Шелеста привчав сина до науки. У чотири роки, спогадував Петро, він та брат вивчили букви, цифри, а потім навчилися читати, писати і рахувати, а у 1914 р. пішли до земської школи, в якій провчилися чотири роки. Запам'ятались маленькому Петру й розповіді батька про їхній родовід від “козацького сотника Василя Шелеста” [11, с. 31].

Згодом вибухнула Перша світова війна, потім відбулась Лютнева революція 1917 р.: “...Життя, - згадував П. Шелест, - ставало все важчим ібільш складним. Царя немає, попа теж немає... А тут почався розбій, з'являлися банди, а відомо, що трудова людина не може жити без порядку, визначеності, закону... Ішла політична, ідеологічна, класова боротьба, але її мало хто розумів з простих людей” [18, с. 63]. Батько - Юхим Дмитрович обміняв свій будинок на будиночок, який взяв на додачу 12 пудів зерна-сурогату. Велика родина виживала досить нелегко в умовах розрухи, голоду, політичної нестабільності. Доводилося і Петру з матір'ю зі свого села ходити пішки за 30-40 верст на хутори, щоб принести трохи муки, макухи або якоїнебудь їжі [11, с. 40]. Під час одного з таких походів був дуже сильний буран і вони буквально дивом вижили. Згадував Шелест, де доводилося роз “їджати за сіллю: “Пуд солі на петлях через плече, верхи на буфері між вагонами - такий, здебільшого, був наш транспорт. Скільки померло, у тому числі і моїх однолітків, під колесами залізничних вагонів! Але сіль - це велика коштовність, на неї можна було виміняти хліб, зерно. Голод примушував, гнав із рідного місця у пошуках порятунку від голодної смерті” [18, с. 63].

Петро працював на різних роботах. У лютому 1920 р. став батраком у заможного селянина. Цей селянин поставив ціль: служити не менше року і працювати по господарству. Цей заможний селянин давав родині Шелеста чотири пуди пшениці, а після закінчення терміну роботи обіцяв одягнути Петра “від ніг до голови”. Було домовлено, що у разі якісного виконання роботи хлопчик отримає ще пуд пшениці і пуд проса. У пору жнив новий господар Шелеста наймав ще 10-15 робітників, чоловіків і жінок. Працювали вони “від ранньої зорі до пізнього вечора, ночуючи часто прямо в полі” [9, с. 86]. Поступово молодий хлопець розпочав кар'єру і закінчив Ізюмську радянську-партийну школу, став секретарем Боровського райкому комсомолу, вступив до лав КП(б)У. У Харківі навчався в інженерно-економічному інституті, служив в Червоній армії, а у 1940 р. він став секретарем Харківського міського комітету 
КП(б)У з питань оборонної промисловості. Протягом 1948-1954 рр. Шелест керував заводами у Ленінграді та Києві, при ньому було налагоджено серійне виробництво літаків Ан-2 та Іл-8. В квітні-грудні 1956 р. саме Петро Шелест очолював Комісію Верховної Ради СРСР 3 реабілітації незаконно репресованих громадян на території Київської і Вінницької областей [6, с. 56]. 3 лютого 1957 р. він став першим секретарем Київського обкому КП України. А у липні 1963 р. пленум ЦК КПУ обрав Петра першим секретарем Комуністичної партії України замість Миколи Підгорного, який став секретарем ЦК КПРС. Займав він цю посаду до травня 1972 р. Один зтих хто працював з Петром Шелестом Юрій Єльченко згадував: “Був Петро Юхимович працівником принциповим, наполегливим, сильним, дуже жорстким, потрібні якості постійно і без коливань. Не пасував перед найвищими головами, міг прямо сказати те що думає і захищати свою точку зору, без огляду на керівника. Будемо говорити відверто - це не завжди і не всім подобалось. Безумовно, тут виявлялись і його природні людські риси. Ми знали його як лудину сильного характера, безхитрісну людину. Бував він і брутальним, не соромився і у висловах. У побуті (де доводилось кілька разів бути з ним у такій обстановці) поводив себе дуже просто, розкуто, був відвертим, говорив про сімейні справи. Звертав на необхідність, недивлячись на багато роботи, час на виховання. Вважав, що своїх синів виховав людьми гідними. Знаю, що це так і було” [8, с. 121].

П. Шелест став символом та поборником українства. Він з прихильністю ставився до процесів українізації 20-х років, прагнув відродити історію та культуру та іiі позитивні елементи, відстоював українську мову. Петро Юхимович мав за меті українізувати керівний апарат і вимагав, щоб українська мова стала мовою діловодства. Саме це в 1960-х рр. три чверті керівних посад обіймали українці. У 1969 р. вийшла нова Шелеста "Україно наша Радянська", яка своїми культурними та національними мотивами викликала неоднозначну реакцію в Москві [18, с. 107]. Книга показала відкриту цікавість республіканської партійнодержавної еліти своєю історією та культурою. У книзі “Україно наша Радянська" багато уваги Шелест приділяв важливості вивчення історії України і робив акцент на велику історію українського народу, в першу чергу йдеться про козацтво, де розкривається суть українського народу. Згодом були опубліковані такі джерела з української історії, в тому числі козацький “Літопис Самовидця", “Львівський літопис" та “Острозький літописець” [15, с. 475].

Поява такої книги не була випадковою. Українське козацьке коріння визначали спосіб мислення Петра Шелеста. Для нього все українське було рідним. Але водночас він цілком усвідомлював себе як радянського українця [4, с. 77]. Неодноразово за занадто україноцентричну позицію, на Петра Шелеста надходили анонімні листи. В одному з таких листів, прямо ставили питання: “До якої пори ця вакханалія на ідеологічному фронті Української РСР буде продовжуватися? Коли, врешті-решт, буде наведений більшовицький порядок? Просимо глибоко, з опитуванням народу перевірити стан ідеологічної роботи в Україні". Газета "Правда" за підтримки, яка 16 грудня 1965 р. без оглядки на Шелеста опублікувала статтю секретаря Львівського обкому партії Валентина Маланчука “Сила великой дружбы” [17, с. 138]. В ній критикувався націоналізм. Причому це був не удар, а справжнє обвинувачення в сторону ЦК КПУ, яке прогавило український націоналізм. Шелеста сильно збентежив цей виступ. I саме за прорахунки Петра Шелеста в ідеології призвели до його звільнення в 1968 р. [7, с. 95].

Підтримав та схвалив Петро Юхимович Шелест ініціативу української інтелігенції щодо увічнення пам'ятних місць, пов'язаних з історією козацтва. Він не лише підтримав висунуті пропозиції громадськості, а й мав намагання, що внаслідок проведення цієї роботи буде створений великий козацький постамент на острові Хортиця. Петро Шелест писав у щоденнику: “Дивився питання, котрі пов'язані з будівництвом етнонаціонального музею в Україні, а також стелу на честь Січі на острові Хортиця. Все це вкрай необхідно для історії нашого народу, для покоління, для виховання патріотичних почуттів. Дуже погано, що деякі українці не знають історії власного народу і не хочуть робити нічого для увічнення культури, побуту і боротьби власного народу” [11]. 18 жовтня 1965 р. вся територія Хортиці постановою Ради міністрів УРСР була проголошена історико-культурним заповідником. На острові 
планували відновити ландшафти та рослинність козацької доби, побудувати музей козацтва, козацькі зимівники та інші об'єкти, пов'язані з його історією. Але встигли побудувати лише Музей козацтва. За часів Володимира Щербицького Музей козацтва на острові реконструювали в Музей історії Запоріжжя. Але Хортиця залишилася заповідником. Мешканці острова не мали нічого будувати, а до острова було заборонено навіть причалювати човнам [17, с. 143].

На початку 1960-х рр. Петро Юхимович Шелест був одним із тих хто надихнув на створення унікальної української енциклопедії - двадцятишеститомної “Історії міст і сіл Української РСР”. Ідея фундаментальної історичної праці зародилася у Шелеста, коли він був першим секретарем Київського обкому КПУ. Під час чергової подорожі по області машина застрягла в болоті, і він змушений заночувати в найближчому селі. Там, у помешканні одного діда, Шелест випадково звернув увагу на дореволюційну книжку, в якій містився докладний опис села, зроблений священиком [17, с. 137]. Ознайомлення з книжкою породило бажання Шелеста створити сучасну наукову працю, яка б повністю розказати про 40 тисяч населених пунктів України, де б значну роль приділялось козацтву. У травні 1962 р. президія ЦК КПУ прийняла рішення підтримати видання про історію міст і сіл Української РСР. Головну роботу вищі партійні голови поклали на заступника голови Ради Міністрів УРСР Петра Тронька та редакцію Української Радянської Енциклопедії на чолі з Миколою Бажаном. [9, с. 295]. Значна кількість інформації відзначала заснування сіл та міст козацтвом.

Проведення П. Шелестом автономістського курсу, його певна самостійність у вирішенні питань, та прояви культурної автономії не могли сподобатися союзному керівництву. Л. Брежнєв поступово готував передумови для усунення Петра Юхимовича від влади. Вони визрівали разом зі зміцненням влади Л. Брежнєва в Москві та позицій В. Щербицького в Україні. Саме в березні 1972 р. П. Шелест піддіний всеосяжній критиці з боку Москви за “недоліки у справі інтернаціонального виховання трудящих і примиренське ставлення до проявів націоналізму”. У травні 1972 р. Петра Юхимовича звільняють від обов'язків першого секретаря ЦК Компартії України й призначають заступником голови Ради міністрів СРСР. Було розпочато спеціальну кампанія проти його книги "Україно наша Радянська", на неї підготовлено негативну рецензію. У рецензії йшлося про те, що автор “відходить повністю від курсу партії, не дає класового аналізу й оцінки історичних відносин, ідеалізує українське козацтво і Запорозьку Січ” [17, с. 144]. Внаслідок цього видана накладом 100 тис. примірників, книга була вилучена з продажу і бібліотек.

Отже, позитивне ставлення Петра Шелеста до козацької тематики, пов'язані $з$ його родиною, обумовлені розповідями про козацького ватажка “Шелеста", що не могло не викликати гордість за своє минуле. Козацьке минуле пов'язало Петра Юхимовича з усім українським. Це визначало його політику на посаді першого секретаря КП(б)У, створило стриятливі умови для розбудови архітектурних комплексів, заповідників, присвячених історії українського козацтва. Козацька тематика яскраво відображалась і у енциклопедичних та інших виданнях, що вийшли друком “в часи Петра Шелеста", зокрема "Історія міст і сіл України”, його книга "Україно наша Радянська".

\section{Джерела та література:}

1. Демиденко О. Внесок державних структур в охорону та увічнення пам'яток українського козацтва в 1956 - 1980-х pp. Укр. іст. зб. 2005. Вип. 8. С. 339-347.

2. Демиденко О. Діяльність Українського товариства охорони пам'яток історії та культури зі збереження об'єктів козацької доби (друга половина 1960-х-1980-ті pp.). Icm.геогр. дослідж. в Україні. 2006. Вип. 9. С. 409-425.

3.Демиденко О. О. Проблеми збереження історії козацтва в пам'ятках культури України. Історія украӥнського козацтва : нариси у 2 т. Київ, 2007. Т. 2. С. 462-478.

4. Демиденко О. О. Увічнення та збереження історії козацтва в пам'ятках культури України (1945-2005 рр.) : автореф. дис канд. іст. наук : 07.00.01. Київ : Ін-т історії України НАН України, 2006. 19 с. 
5. Жадько В. О. Некрополь на Байковій горі. Київ : Фенікс, 2008. С. 105-107, 164, 267.

6. Кіндрачук Н. Соціально-культурні процеси в українському етнічному середовищі УРСР 60-70 рр. ХХ ст.: динаміка, тенденції, наслідки : дис. ... д-ра іст. наук : 07.00.01 / Одес. нац. ун-т імені I. I. Мечникова. Одеса, 2021. 500 с.

7. Кіндрачук Н. Простір українського національного «Я»: 60-ті - 70-ті pp. XX ст. : монографія. Івано-Франківськ : НАIP, 2020. 502 с. 1997. $464 \mathrm{c}$

8. Малий словник історії України. Т.1 / відп. ред. В. А. Смолій. Київ : Либідь, 1997. $464 \mathrm{c}$.

9. Малий словник історії України. Т.2 / відп. ред. В. А. Смолій. Київ : Либідь,

10. Музиченко Я. «Неправильний» Шелест. Україна молода. 2008. 12 лют.

11. Петро Шелест: Справжній суд історії ще попереду: спогади, щоденники, документи, матеріали / упоряд.: В. К. Баран та ін. ; за ред. Ю. І. Шаповала. Київ : Генеза, 2003. $808 \mathrm{c.}$ 14 лют.

12. Пономарьов В. 100 років від народження Петра Шелеста. Радіо Свобода. 2008.

13. Савельєв В. Л. Чи був П. Ю. Шелест виразником «українського автономізму»? Укр. іст. журн. 1991. № 4 (361), квіт. С. 94-105.

14. Саган О. Петро Юхимович Шелест. Міфи і реалії. URL: Pseudology.org (дата звернення: 03.09.2021).

15. Трофимова С. Охорона козацьких пам'яток в УРСР. Наук. зап. : зб. пр. молодих вчених та аспірантів. Київ, 2011. Т. 22. С. 370-378.

16. Шаповал Ю. І. Шелест Петро Юхимович. Політична енцииклопедія / редкол.: Ю. Левенець (голова), Ю. Шаповал (заст. голови) та ін. Київ : Парламент. вид-во, 2011. 781 с.

17. Шаповал Ю. І. Петро Шелест у контексті політичної історії України XX століття. Укр. іст. журн. 2008. № 3. С. 134-149.

18. Шаповал Ю. І. Петро Шелест. Дитинство та юність майбутнього керівника УРСР. Укр. правда. 2013. 24 груд.

\section{References:}

1. Demidenko, O. (2005) The contribution of state structures in the protection and perpetuation of monuments of the Ukrainian Cossacks in 1956-1980's. Ukrainian Historical Collection, issue 8, pp. 339-347. [in Ukrainian].

2. Demidenko, O. (2006) Activities of the Ukrainian Society for the Protection of Historical and Cultural Monuments for the Preservation of Objects of the Cossack Era (second half of the 1960s 1980s). Historical and geographical research in Ukraine, issue 9, pp. 409-425. [in Ukrainian].

3.Demidenko, O. (2007) Problemy zberezhennia istorii kozatstva v pam'iatkakh kultury Ukrainy History of the Ukrainian Cossacks, vol. 2, pp. 462-377. [in Ukrainian].

4. Demidenko, O.O. (2006) Perpetuation and preservation of the history of the Cossacks in the cultural monuments of Ukraine (1945-2005). Ph.D. Thesis. Kyiv: Institute of History of Ukraine, National Academy of Sciences of Ukraine. [in Ukrainian].

5. Zhadko, V.O. (2008) Necropolis on Baikova Hill. Kyiv: Feniks, pp. 105-107, 164, 267. [in Ukrainian].

6. Kindrachuk, N. (2021) Socio-cultural processes in the Ukrainian ethnic environment of the USSR 60-70 rr. XX st.: dynamika, tendentsii, naslidky. Doctor. Thesis. Odesa: Odesa I. I. Mechnikov National University. [in Ukrainian].

7. Kindrachuk, N. (2020) The space of the Ukrainian national "I": 60-ti-70-ti rr. XX st. IvanoFrankivsk: NAIR. [in Ukrainian].

8. Smoliy, V.A. ed. (1997) Small dictionary of the history of Ukraine. T.1. Kyiv: Lybid. [in Ukrainian].

9. Smoliy, V.A. ed. (1997) Small dictionary of the history of Ukraine. T.2. Kyiv: Lybid. [in Ukrainian]. 
10. Muzichenko, Ya. (2008) "Wrong" Shelest. Ukraine Young. 12 Febr. [in Ukrainian].

11. Shapoval, YI. red. (2003) Peter Shelest: "The true court of history is still ahead": memories, diaries, documents, materials. Kyiv: Heneza. [in Ukrainian].

12. Ponomarev, V. (2008) 100 years since the birth of Peter Shelest. Radio Liberty. 14 Febr. [in Ukrainian].

13. Savelyev, V.L. (1991) Was P. Yu. Shelest an expression of "Ukrainian autonomy"? Ukr. ist. magazine, no. 4 (361), pp. 94-105. [in Ukrainian].

14. Sagan, A. Petro Yukhimovich Shelest. Myths and realities Available at: 〈Pseudology.org> [Accessed 03 September 2012]. [in Ukrainian].

15. Trofimova, S. (2011) Protection of Cossack monuments in the USSR. Naukovi zapysky : zbirnyk prats molodykh vchenykh ta aspirantiv, t. 22, pp. 370-378. [in Ukrainian].

16. Shapoval, Y. I. (2011) Shelest Petro Yukhimovich. In: Political Encyclopedia. Kyiv: Parlamentske vydavnytstvo, pp. 781. [in Ukrainian].

17. Shapoval, Y. I. (2008) Petro Shelest in the context of the political history of Ukraine in the twentieth century. Ukrainskyi istorychnyi zhurnal, no. 3, pp. 134-149. [in Ukrainian].

18. Shapoval, Y. I. (2013) Peter Shelest. Childhood and youth of the future leader of the USSR. Ukrainian Truth, 24 Dec. [in Ukrainian]. 